\title{
MANAGING DIVERSITY: THE GOVERNMENT OF A MALAYSIAN HAWKER PLACE
}

\author{
NORMAN BACKHAUS \\ University of Zurich
}

\begin{abstract}
Selling and consuming street food has a long tradition in urban areas of Asia. While the preparation of food, the appropriation of space, and the sale itself follow certain rules, some of them are informal and not always in line with government regulations. However, even though the street vendors (or hawkers) are practicing their trade in a gray area between formality and informality many hawker places function surprisingly well. It is the aim of the paper to analyze the functioning of such a hawker place. As case study serves Changlun, a small town in the Malaysian state of Kedah, where qualitative interviews with hawkers but also officials were conducted. Results indicate that the government of this hawker place is a consequence of an intricate entanglement of practices, which include a tolerant administration but also compliant hawkers and customers liking this place. However, this entanglement is not without conflicts and problems. The hawkers are economically vulnerable and do not have many alternatives to generate income. Consequently the paper ends with recommendations that should enable the functioning of a hawker place as a traditional and well-regarded place to meet and eat and a space for underprivileged people to earn an income.
\end{abstract}

\section{Introduction}

Throughout the world street food is regarded as something special for various reasons: Street vendors sell traditional dishes that their customers would or could not prepare at home anymore (Swislocki, 2009), they create a space for casual meetings (Khoo, 2009) and a sense of place (Shamsuddin \& Ujang, 2008); (Wijaya et al., 2013). They provide cheap calories to workers (Etzold, 2013), and with their sometimes almost artistic performances they are also tourist attractions (Henderson et al., 2012); (Steel, 2012). However, they are also regarded as a health problem (Mukhopadhyay et al., 2002); (Kampen et al., 1998), (Burusnukul et al., 2011) (Samapundo et al., 2015), as occupiers of public space (Hackenbroch, 2013), as obstacles to traffic (Burnett \& Newman, 2014), or unfair competition to regular restaurants. This list of characteristics can be extended considerably of course. Moreover, hawker practices change from region to region (cf. de Cassia Vieira Cardoso et al., 2014) and from place to place, so that we cannot speak of a generic hawker place that more or less encompasses all the traits of the practice of street vending. Rather each region and even each place has its own characteristics. One common aspect however is that the hawkers are seeking the close proximity to their customers, which is their way to compete with restaurants and fellow hawkers (cf. Boone \& Van Dijk 1998). Hence, they are looking for niches for their stalls at streets, crossroads, overpasses etc.

This case study examines the street hawking situation in Changlun, a small town in the north of the Malay Peninsula in order to analyze the intricacies and subsequently the "management" of hawker places. The geography of a hawker place does not only consist of the street vendors making their appearance and doing business on the streets but also of their customers with their needs and desires, the passers-by in cars or other vehicles, but also government employees that have to regulate public space and with it street vending. The combined and aggregated practices that form a hawker place may also be 
called a site (according to Schatzki, 2002), which is more than just a physical space in a town or a city but encompasses also social, economic and political aspects that are related to it.

Knowing about the gray area (Yiftachel, 2009) between formality, informality, and even illegality in which many street vendors pursue their business (Etzold et al., 2009) it is surprising that many hawker places function quite well and this has gone on for many years. Hence, this paper focuses on this functioning and how it contributes to what must be called a delicate balance between "traditional" form of appropriation of space and the "modern" requirements of managing space by government authorities. Hence, the practices of involved stakeholders in this balancing will be looked at more closely.

After a brief description of the methods used, I will present the different practices that ultimately form the hawker site at the case study area. In the discussion I will interpret the findings in order to explain the functioning of the hawker site and give some concluding recommendations.

\section{Methods and Context}

Since this is research with an exploratory character a qualitative approach was taken. During two weeks in January 2014, 22 hawkers, 2 government employees, and 4 NGO representatives were interviewed in the case study area. Moreover, extensive observations and informal talks as well as frequent meals taken at hawker stalls contribute to the overall image of the hawker place. The interviews were conducted together with a research collaborator. Subsequently they were transcribed, coded and analyzed using MAXQDA.

The case study area is embedded in a specific context that shall be explained briefly here. It is a small town situated in the North of the Malay Peninsula near the Thai border. An interstate road that connects the Northern state of Kedah with Thailand leads through the town and causes a lot of traffic (but also brings customers to the hawkers). Moreover, large educational institutions are situated near the town and many staff and students reside there during college terms. With less than 2000 inhabitants it is a small but growing town. Many of its surrounding lands were converted into rubber or oil palm plantations. There are no significant tourist attractions for which foreign or domestic tourists would specifically come to the town. The hawkers concentrate around the main road that crosses the interstate road but there are also some stalls at thoroughfares leading to new residential areas. Even though there are quite a few hawker stalls around, the place does not portray a congested appearance. This, however, changes once a week in the evening when the night market comes to town. Its stalls are closely lined up and many people gather here to buy goods, eat and meet. Traffic at these times is congested too. Even though the town is not a big city where hawkers have increasing difficulties to set up their stalls, there is some competition among the hawkers for space and pressure from the municipality (the majlis) to move them into formal hawker places.

\section{Hawkers' and Other Stakeholders' Practices}

The hawker site is composed of practices of different stakeholders. Together they form and build this place and give it its distinct appearance and feel. In the following sections these practices that are taking place in the case study area are grouped and described; subsequently, they will be looked at from the perspective of the governance of this specific hawker place. But first a brief overview on who the hawkers are is due.

\section{The Hawkers' Background}

Hawkers have been serving customers in the small town for a long time. Some of the interviewed persons have set up their stalls thirty years ago and practiced ever since, others just set up their stall for the first time (and in one instance gave us the honor to be their first customers). The background of the hawkers is as diverse 
as their products. Most of them come from the wider area around the town (some also cross the border from Thailand) where they practice their trade. Some married a person (usually the husband) from the area, others came here for work and started hawking after their retirement or as a sideline. None of them is affluent or rich but all interviewed persons said that they more or less come by with what they earn (usually from different income sources). However, many hawkers are indebted for various reasons (for buying a house or a car but some also for buying a hawker stall). Only one of the indebted had a bank loan, all others resorted to micro finance schemes (i.e. Tekun or Amanah Ikhtiarl), pawn brokers or relatives in order to get credit since they generally do not have the necessary collateral for a bank loan. Most people working at the stalls are the owners who work on their own. But some owners also hire employees, including laborers who work in their own stalls in the morning, and are employed by other hawkers in the afternoon. Those operating a small stall usually have additional income sources, ranging from rubber tapping, to tailoring, to office work.

\section{Food and Its Preparation}

The variety of food that is sold on the streets of this town is great. The smaller stalls mostly specialize on one dish or a small variety of dishes whereas bigger stalls (that often are not mobile) work more like restaurants with different kinds of dishes. Besides the food stalls there are also drink stalls that almost exclusively serve hot and/or cold drinks. By deciding on a dish they want to serve the hawkers must take into consideration different aspects:

\footnotetext{
${ }^{1}$ Both Tekun and Amanah Ikhtiar are Malaysian micro credit schemes, for which the borrowers do not need collaterals as with a bank. However, their proposed business schemes are being closely scrutinized before they receive any money. Moreover, borrowers who pay back their debt and interest in time will have the chance to get higher sums for subsequent loans. While Amanah Ikhtiar only lends to women and requires them to follow a local lenders group (to discuss business ideas and get help with setting up a business plan or with repaying the loan), Tekun caters also for men and does not require the lenders to enter a lenders group.
}

- $\quad$ They have to decide whether they can or want to prepare the meals themselves or rather resell food prepared by others.

- $\quad$ Depending on the dish they want to serve and the possibilities they have at home, they have to decide whether to prepare meals on site and on demand or before that (usually at home).

- Depending on the time they want to spend hawking they must limit their dishes to certain types (i.e. breakfast, lunch, dinner, snack).

- The hawkers' cultural background may also limit their options (i.e. to serve only halal food).

- $\quad$ They need to decide whether to compete with other hawkers offering the same goods or find another niche.

These decisions have an influence on the pattern of the hawker site. In the early morning little cakes (kueh) that have been prepared before at home are sold at small tables as well as roti canai, a bread-like dough that is eaten with a sauce. This popular dish has become a Malaysian staple food even though it originates from the Indian subcontinent. Nasi lemak, rice boiled in coconut milk and served with sambal sauce (and often chicken meat, egg and/or cucumbers) and packed into triangular banana leaves or newspaper is a traditional Malaysian breakfast dish. Drinks are basically served throughout the whole day, most people start with a cup of hot tea or coffee but the stalls also offer sugar cane water, fruit juices and cendol (something between drink and dessert). While the "breakfast" hawkers are finishing preparing and selling their meals between 9 and $10 \mathrm{AM}$ their colleagues specializing in lunch dishes start setting up their (mostly bigger) stalls where they sell different dishes, most of all nasi campur, a buffet-style traditional Malayan dish on the base of rice and a great variety of vegetable, fish, or meat fare. Others sell fried noodles (mee goreng), soup (bihun, tom yam), rice porridge $(\mathrm{moi})$ and many other dishes for lunch. Sweets or pastries made of rice flour (e.g. apam balik, putu mayam), are usually sold in the afternoon (but not exclusively). In the evening the variety of dishes is even greater and ranges from burgers to tofu drumsticks (yong tofu) to 
kuayteow, a noodle soup originating from China and Vietnam.

The preparation of all these dishes involves tasks that are not visible for the customers but that, nonetheless, have an influence on the hawker site. Even with dishes that are cooked on time and in front of the customers the hawkers need to do some preparation at home (i.e. buying or collecting ingredients on the market or with wholesalers, chopping vegetables, washing rice or making dough). Those who sell ready made meals such as nasi campur do all the cooking (mostly the women do the cooking) at home and transport the dishes in plastic or iron containers to their stall. All these steps involve careful planning. In contrast to restaurants that have kitchens and pantries the hawkers cannot store any food at their stalls and have to transport everything. For some of them this means that they need to have access to a car or a truck. Also those who merely resell kueh that were prepared by others need to organize the delivery by their friends to be able to sell on time (i.e. before dawn).

The visible aspects of food preparation sometimes involve considerable skills that are also attractive for customers and onlookers, for instance when dough is swung through the air to thin it, tea or coffee is foamed by pouring it from great heights (teh/kopi tarik), sugarcane is pressed, or pastries are baked in makeshift waffle irons. Less spectacular but still important is the display of the dishes to make them appear fresh and appetizing. Since competition is increasing it happens that some hawkers offer the same dish not far apart from each other. While for some treats the market seems not to be saturated yet (i.e. for kueh) others (i.e. roti canai and cendol sellers) feel the pressure. Some rely on their good reputation, others react with specialization to the competition. A woman offering cendol, for instance, started using palm oil as an ingredient to distinguish her cendol from other providers. A roti canai cook serves a little fish with the sauce that makes his stall stick out from the others. So far no one planned to lower prices since they are working with very little margins and they do not want to enter a race to the bottom.

\section{Appropriation of Public Space}

When asked about how they occupied the space where they are selling their goods, most hawkers said that they more or less were able to set up their stalls where they wanted to. Moreover, they were rarely complaining about congestion or a lack of space (except for the night-market, see below) even though they often mentioned that there is little space. However, when asked about how they were able to appropriate their space, it became clear that it was rarely that easy. The way hawkers find and appropriate their spatial niche is very diverse. Most have a kind of dish in mind when they decide to start hawking. As seen, this determines the "shift" or temporal space they occupy (only very few open their stalls for the whole day), sometimes it is the other way round and the time slot determines the range of dishes that can be offered (i.e. if a hawker has an additional occupation that requires him/her presence elsewhere). If a hawker is lucky (which is increasingly less so with more and more people entering the business) he/she finds an open and unoccupied and uncontested space to set up the stall. Small and mobile stalls (i.e. roda tiga, three wheelers) have obviously better chances to find such a spot than larger warungs, restaurant type stalls (for a schematic plan of a hawker place see the figure 1). The first come, first served rule is respected and if a hawker regularly occupies a place it will not be contested. If an established hawker needs to be absent for a while, his/her neighbors will see that no other hawker occupies this space.

In this respect Ramadan is an exception, at least for the Muslim hawkers. Some of the hawkers serving breakfast still continue selling during the fasting month but only until sunrise and with lesser quantities. Most other hawkers say that they do not sell, that this is their "holiday" month. Some of the hawkers serving dinner do so but for a much shorter time (i.e. from dusk to 8 or $10 \mathrm{PM})$.

Most are not so fortunate to find a good spot that suits their requirements. Often there is already a hawker claiming a coveted space. 

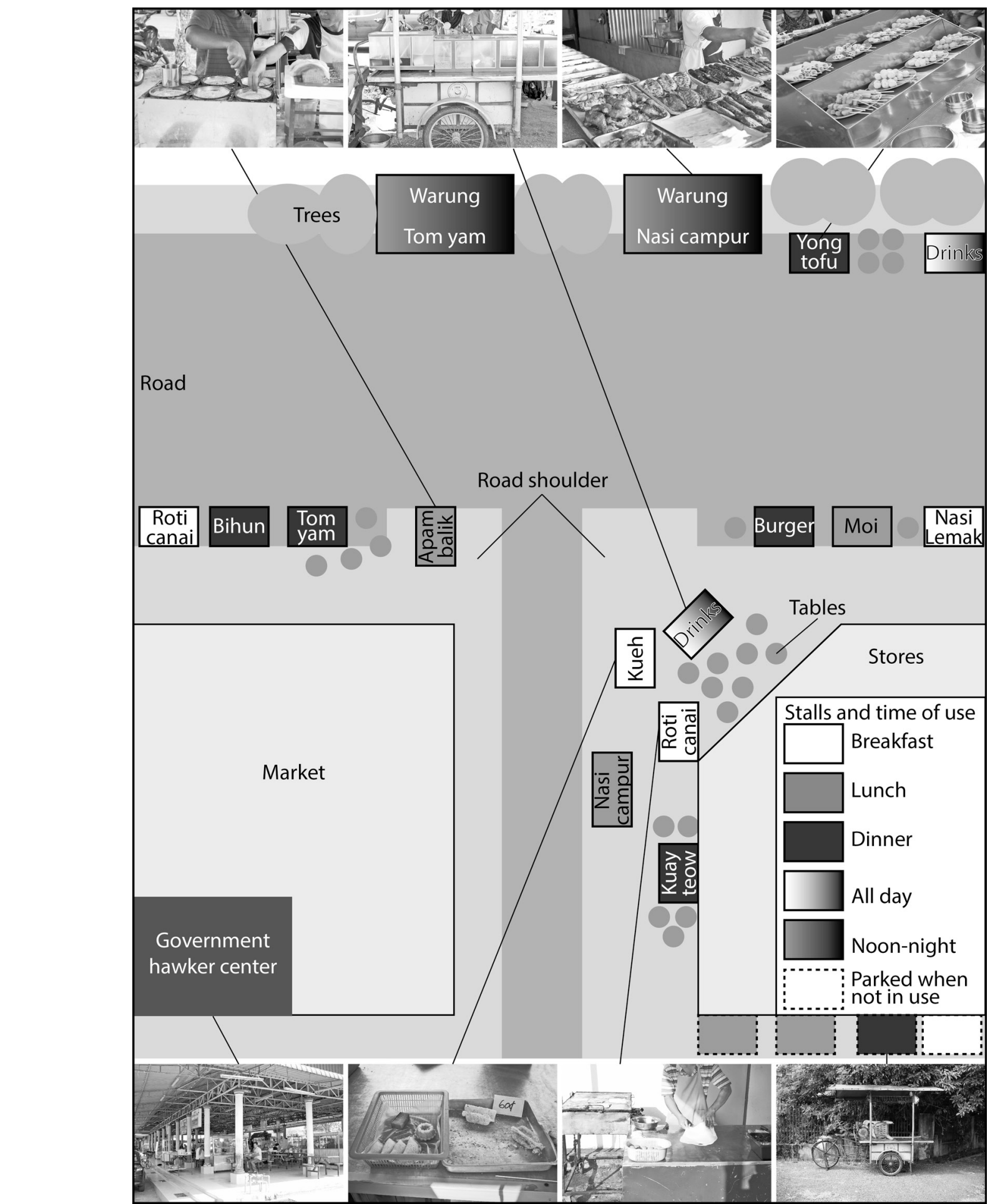
Since they do not have a legal right to this land, there is also no clear boundary regarding this kind of appropriation. Often claims are staked with placing chairs and tables around a stall. Nevertheless, negotiations start about whether and how a new hawker can set up his/her stall beside an existing one. Often there is money involved. Either the newcomers have to pay "goodwill" or "coffee" money as a fee or pay rent to the old-established hawkers. Consequently, an established hawker can surround his/her stall with suitable newcomers and hence is able to stave off competitors. Often these so-called anchor hawkers are selling drinks. It is in their interest to have food selling stalls beside them, because eating and drinking go hand in hand and in many cases this is regarded as a profitable arrangement for both even if the newcomers have to pay rent. Depending on the dishes served, different hawkers occupy the same spot during a day. Thereby, after the use of the stalls they are being wheeled away around a corner, behind a building and left there basically unguarded and unheeded.

As for the larger stalls this might not necessarily work for the mere fact that they need more space and usually operate like a restaurant serving food and drinks. In these cases people interested in setting up a warung have to wait for an oldestablished hawker to move on, or to buy off the place. Prices for this go up to RM30,000 (roughly US $\$ 8,400$ or $€ 7,400$ ) for a roofed place with kitchen and space for a dozen tables, which is remarkable since there is no guarantee that the buyers can stay there.

Besides these informal deals hawkers have also the possibility to officially rent space either from private people or the government. In our case study area there are two government owned hawker places: one near the wet market and one at the road where other hawkers have set up their stalls. The place includes a small kitchen and approximately half a dozen tables that are bolted to the floor. The conditions are regarded as fair; the rent is usually a little higher than for an informal place but then there is more security for keeping the space.

\section{Sharing Space with the Night-Market}

Once a week there is a night-market in town, which occupies part of the hawker place. 170 stalls selling food an all kinds of other goods are serving people coming in great numbers. The hawkers at the night market are not the same as the ones working during daytime respectively on other weekdays, of whom many declared that they are not present when the night-market is held (even if they have their stalls at a different place). For them the market is too busy and hectic they say. Moreover, they complain that the night-market hawkers use their tables and chairs and leave rubbish. The hawkers working at the night-market in contrast often move around and go from night-market to nightmarket in different towns and thus make weekly rounds (for the intricacies of night-market arrangements see Roslin \& Melewar 2008; Chiu 2013; Milgram 2014). Some are also present at day-markets (nat). They always occupy the same places at these markets and say that they have been allotted to them by government officials ten years ago and never changed since. However, in order to keep one's place regular attendance is important.

While there is a considerable competition among the hawkers (almost all persons interviewed knew about a competitor serving the same or similar foods in the area), they do not complain much about this kind of rivalry even though they concede that it is challenging. However, the night-market itself and especially so called "wild" hawkers that show up only occasionally (i.e. durian sellers) operate without license and without allotment are scorned because they are accused of shedding a bad light on the hawkers in general. Indeed they often occupy places that are deemed as too close to traffic and therefore dangerous. The hawkers' associations that commit themselves to the cause of the hawkers try to negotiate between traffic police, hawkers and "wild" hawkers to find solutions for all. Board members of the hawkers' association claim that they usually are able to mitigate between different stakeholders. However, they also report that especially in the bigger towns large areas are being "cleared" and hawkers 
urged to move away or to go into government hawker centers. Also they complain about shrinking numbers of members. This is regarded as a consequence of the hawkers' ignorance of the association's tasks.

\section{The Government and How It Is Perceived}

The term "government" encompasses a variety of institutions on different levels and even more different practices that are enacted by actors that interpret their role and tasks differently. Hence, it is difficult to establish a clear view of "the government's" (in the sense of political administration) position on the hawker site. We talked to officials that are responsible for the licensing of hawkers on the district level about their opinion and issues regarding hawking in public space. Technically the occupation of public space for commercial purposes is not allowed without the consent of the district council (majlis daerah). A hawker applying for a license at the district office has to fill in a simple form and also needs to draw a sketch of the place where he/she wants to set up the stall. Hence, the hawkers in our case study area (except those in the government stalls and those working on the night-market) operate in the gray area between formality and informality. The reason why officials do not simply remove the hawkers from the streets was explained with the acknowledgement of traditions and the importance of this source of income. Street food is regarded as a Malaysian tradition that the public likes and does not want to miss. Hence, the officials' position is not focused on the "clearing" of the streets but rather on how to find a way to address problems that are associated with hawking, mainly traffic jams and hygiene. The hawkers are not completely free floating or uncontrolled since they are required to have a license issued by the commission on commerce (Suruhanjaya Syarikat Malaysia (SSM) at 40-100 RM/year and to be vaccinated against typhoid. If they do not have a license or a vaccination they can be fined or their stalls can be confiscated. The same applies for stalls that do not meet basic hygienic requirements. The officials interviewed claimed that all hawker sites are controlled routinely, roughly every two months. This statement somewhat contrasts with hawkers claiming to not have been controlled since they started twenty years ago. Nevertheless, it happens that hawkers get fined and their stalls confiscated due to unhygienic practices or an especially dangerous positioning on the street.

This rather tolerant practice is accompanied by efforts to bring hawkers into government stalls where they are out of anyone's harms way. Thus they follow a trend that has been implemented rigorously in Singapore since its independence (Henderson et al., 2012). While the hawkers generally have a good relationship with government officials and state that treat them fairly, they strongly oppose attempts to relocate them into government stalls. They fear to become too far removed from their customers who would not frequent them anymore if they are not positioned directly at strategic spots on streets, crossroads or market places.

A new development regarding the relation between hawkers and the government is the prime minister's proposal to forgo the license fee for hawkers for three years to give the hawkers some financial help to compensate them for rising petrol prices (that are expected due to the removal of government subsidies demanded by WTO). This speech (cf. Bendahara \& Cheema, 2014) is remarkable for two reasons: first, the prime minister shows concern for a distinct group of people and recognizes their vulnerability to economic change and second, his acknowledgement of the importance of an informal trade. The speech stands in stark contrast to the attempted removal of hawker stalls in Telok Bahang (Penang State) that resulted in a brawl between outraged hawkers and government officials. The fact that Penang State is ruled by the opposition party shows that the hawkers have entered political discourses.

\section{Income}

The hawkers' income through street food varies considerably according to the type of food, the time spent at the place and costs. The rates for certain services or for employees, 
however, are quite consistent. A dish washer gets approximately RM20/d, a sales help RM30 and a cook RM50. The net income per day ranges from RM100 to RM500, while the gross earnings can be up to five times more. The size of the stall does not necessarily indicate the capacity to earn income. Generally bigger stalls have more sales, but not always more income for the owner. The margins are quite different as well and range from $20 \%$ to $75 \%$. The hawkers more or less agree that an income of $300 \mathrm{RM}$ per day is enough for a family. If they work every day (which is rare), their income equals with 9'000 RM/m the salary of a university lecturer. Most hawkers, however, earn less because they are not present every day.

An advantage of this business is that there is daily income, which keeps them going. Experienced hawkers can estimate the number of customers they will serve during the next day(s) quite well. For this they consult calendars and weather forecasts. Rainy days are generally times with lesser customers and lower income. This way they avoid preparing too much or too little and are able to gauge their income at least for a few days. However, they cannot influence their income much and sudden economic changes often hit them hard for they have little reserves (more often they have debts).

\section{Likes, Dislikes and Challenges}

The hawkers generally like their trade, otherwise they would not do it, they say. They appreciate being their own bosses and to interact with their customers ("I enjoy to study people's different characters"), to be outside and in the middle of things. If they get praise for their cooking, they enjoy this as much as the counting of money at the end of the day. They cherish their independence and dislike customers (and other people) telling them how to do their job. Fussy and demanding customers are also not regarded well. Sometimes customers waiting in cars or on motorbikes block other (potential) customers from approaching the stall.

The hawkers face a variety of challenges that refer to the management of the work, prices of raw materials, competition and weather.
- $\quad$ The management of the work is regarded as especially difficult, if there are many customers that want to be served quickly with freshly made food. If the hawkers have no helpers (whom they say are increasingly difficult to find), they have to do many things simultaneously. Especially women say that their days become very long with preparing the dishes at home, looking after their children and working at the stall.

- $\quad$ Rising prices for raw materials do not hit all hawkers the same way since they use different products and often grow some of them themselves. Nevertheless, they cannot simply transfer the raise to their customers who are used to paying a certain amount for certain dishes (for example a certain kueh costs RM1).

- $\quad$ As stated above most hawkers do face competition; not only by hawkers offering the same dish but also by the increasing amount of all sorts of hawkers that enter this site and that vie for space and customers.

- Hawkers are mostly out in the open, only the bigger warung-types have roofs big enough to provide shelter from sun and rain. The smaller ones only have tarpaulins or umbrellas and their customers wait and eat in the open (which is also part of the good experience). To face tropical rainstorms and scorching heat with a small mobile stall is exhausting. Moreover, customers tend to avoid the stalls in extreme weather conditions.

\section{The Future of the Hawker Business}

Asked about the future of their own hawker stall the older respondents said that they are content with what they have and that they would like to continue until someone (in most cases their children) is going to take over the stall from them. The younger ones have other aspirations. They want to upgrade to a bigger stall, a (legal) restaurant, or open a franchise system to sell their 
products. Hence, they regard their present work at the stall as a stepping stone to a more secure and bigger enterprise in the food business.

For the future of the hawker place in their town some are very positive and forecast a bright future for hawking since the town is growing and more people are living there. More cautious people think that more hawkers will increase competition and that this along with rising prices will make it more difficult to generate a decent income. The third group thinks that the hawker place will be cleared and that they would be asked to move into (expensive) government stalls that does not attract enough customers. While these predictions differ considerably they also reveal a measure of uncertainty that arises beyond the concerns which relate to the fluctuating trade cycles.

\section{Discussion: (Self-)government of the hawker place}

We can conclude that the hawker site is not a chaotic assemblage of stalls but rather a formation governed by an intricate web of formal and informal rules and regulations. Its governance is not solely controlled by state officials, even though they play an important role both for stabilizing the site as for challenging it The fact that hawkers need licenses is not only a form of revenue generation (since the hawkers do not pay taxes for their production) but also a recognition of the hawkers' presence in public space. While they do not have the formal right to be at the place where they set up their stalls, they know through the licensing that they are tolerated (and sometimes even appreciated). The obligatory vaccination is well heeded and well known also by the customers. Hence, the good hygiene of hawker food in our case study area is an asset that makes the hawker site more attractive for both local and foreign customers. Compared to other world regions (cf. (Etzold, 2013; Mukhopadhyay et al., 2002; Samapundo et al., 2015) the hygienic aspect in the case study area can be regarded as unproblematic (as a European with a delicate stomach I almost exclusively ate at hawker stalls during field work, stayed healthy and gained weight). Thus, both licensing and obligatory vaccination contribute positively to the functioning of the hawker site. However, in the view of the hawkers the state is also a factor that increases their vulnerability by controlling them arbitrarily and threatening to confiscate their stalls. But mostly the majlis' efforts to clear areas from hawkers and to try to move them into government issued hawker centers is regarded as a threat and contributes to uncertainty. The hawkers' awareness of their associations' efforts to advocate for them with state authorities is not adequate and will probably decrease in the future with less and less hawkers being members of hawker associations. Nevertheless, the associations play an important role in keeping the hawkers in business at their accustomed places by mitigating when problems arise (i.e. traffic issues or with "wild" hawkers).

The hawkers' practices are strongly entangled and also contribute to the governing, the functioning and the appearance of the site. The informal deals around rents, "goodwill" money, and the appreciation of the first-comefirst-served right when appropriating a place forms a connection between the hawkers, an understanding of being of the same kind. The site is not a closed arena and entering it is despite increasing competition - possible and depending on the type of stall and product quite easy even today. While the fact that many hawkers let each other use some of their gear (i.e. chairs, tables, umbrellas) seems to be an arbitrary understanding between neighbors, it is highly regulated and reflected in monetary agreements. The proximity and daily presence of the same group of hawkers at their places tightens the bonds between them. They know each other and exchange information quickly. Hence, they know about surveillance by majlisenforcers before they appear at their stalls and are informed about rumors concerning them. They are also made aware of improvements and changes their competitors make and know when someone is sick or marries etc. While this 
does not make them stick together like a family it contributes to their combined strength and stabilizes the site. The fact that the hawkers in the densely occupied spaces are all Muslims selling halal food contributes to the bonding. The hawker site is indeed multicultural (cf. Wise \& Velayutham, 2009) and stalls serving nonhalal food (ethnic Chinese and Hindu-Indian) are part of it they are always a bit removed from Muslim stalls. Moreover, the concept of halal-toyyibah (Fakihah Azahari, 2010: 1xxvi) that is closely related and ensures that "the [ingredients] are free from any unlawful and impure elements. It shall be good and pure and its consumption brings no harm" strengthens the feeling of belonging together and of contributing to a cause that is important.

For this study we concentrated on the hawkers and did not systematically interview customers. Nevertheless, participatory observation of the lively scene shows that most customers are regulars (especially in the morning) who take the hawker place for granted. While breaking their daily routine, a removal of the hawkers would probably not be very problematic for most of them. However, the restaurants of the towns would not be able to fill the gap left by the hawkers. The increasing number of hawker stalls and the fact that most are satisfied with their business is a strong indicator for customer appreciation.

\section{Conclusion}

We can conclude that the hawker site has its place in Malaysian society generally and particularly in our case study area. It is deeply rooted in the social fabric of urban areas and regarded as a colorful contribution to the appearance of the town. However, the site is far from being unchallenged. The space where the stalls are set up is contested (by other types of street vending such as the night market but also by increasing traffic and shop owners) and what seems to be stable is dependent on tolerance and goodwill by government authorities but also on political developments. It remains to be seen whether the hawker sites in small towns can withstand the trend in Malaysian cities to move hawkers into government provided hawker centers despite the recent support Malaysian hawkers received from the Prime Minister. This paper has shown that the government of the hawker site does not only lie in the hands of officials but is dependent on the intricate entanglement of different stakeholder practices. Hence, the potential for the upkeep of hawker sites that operate in the gray area between formality and informality is there. The vulnerability of the street vendors could be decreased through some measures that I would like to recommend.

The majlis' role in the licensing and controlling of the hawker stall is clear on paper but could be made more transparent and it's efforts to move hawkers into hawker centers should be formulated and conducted more as an offer than as a threat. The hawkers' associations (persatuan penjaja) have lost members. They seem to be unable to convince the hawkers of the benefits they would get with a membership. The acknowledgement of the associations by the majlis (that rather perceives them as antagonists) as partners and a better advertisement of what the associations' do for the hawkers could strengthen their position as rear cover of the hawkers. The informal character of the rules of conduct among the hawkers do not need further regulation as they are self-regulating. The rivalry with the (formal) night market is only regarded as a problem with the hawkers regarding the undue use of equipment and rubbish left. Here the city council together with the vendors of the night market found a solution: immediately after the market has finished a cleaning squad clears the place from rubbish. The willingness of all stakeholders to keep a living tradition that meets the requirements of modern urban life contributes to a lively hawker site and to the wellbeing of street vendors.

\section{References}

Bendahara, A., \& Cheema, S. (2014). PM ask local council to abolish license fee for hawkers and petty traders. New Straits Times. Kuala Lumpur. 
Boone, J., \& Van Dijk, T. (1998). Competition and innovation. De Economist, 146(3), 445-461.

Burnett, K., \& Newman, L. (2014). Urban policy regimes and the political economy of street food in Canada and the United States. In Streetfood: Culture, Economy, Health and Governance (pp. 46-60). London: Routledge.

Burusnukul, P., Binkley, M., \& Sukalakamala, P. (2011). Understanding tourists' patronage of Thailand foodservice establishments: An exploratory decisional attribute approach. British Food Journal, 113(8), 965-981.

Chiu, C. (2013). Informal management, interactive performance: street vendors and police in a Taipei night market. International Development Planning Review, 35(510), 335-352.

De Cassia Vieira Cardoso, R., Companion, M., \& Marras, S. R. (2014). Streetfood: Culture, Economy, Health and Governance. London: Routledge.

Etzold, B. (2013). The politics of street food: Contested governance and vulnerabilities in Dhaka's field of street vending. Stuttgart: Franz Steiner Verlag.

Etzold, B., Bohle, H.-G., Keck, M., \& Zingel, W.-P. (2009). Informality as Agency Negotiating Food Security in Dhaka. Die Erde, 140(1), 3-24.

Fakihah Azahari. (2010). Islamic Finance: Shariah Principles of "Transformation" and "Assimilation." Malayan Law Journal, 1 , lxxiv-xci.

Hackenbroch, K. (2013). Negotiating public space for livelihoods: About risks, uncertainty and power in the urban poor's everyday life. Erdkunde, 67(1), 37-47.

Henderson, J. C., Yun, O. S., Poon, P., \& Biwei, X. (2012). Hawker centres as tourist attractions: The case of Singapore. International Journal of Hospitality Management, 31(3), 849-855.

Kampen, J. Van, Gross, R., Schultink, W., \& Usfar, A. (1998). The microbiological quality of street foods in Jakarta as compared to home-prepared foods and foods from tourist hotels. International
Journal of Food Sciences and Nutrition, 49, 17-26.

Khoo, G. C. (2009). Kopitiam: Discursive cosmopolitan spaces and national identity in Malaysian culture and media. In A. Wise \& S. Velayutham (Eds.), Everyday multiculturalism (pp. 87-104). Basingstoke: Palgrave Macmillan.

Milgram, B. L. (2014). Remapping the Edge: Informality and Legality in the Harrison Road Night Market, Baguio City, Philippines. City \& Society, 26(2), 153174.

Mukhopadhyay, R., Mitra, A., Roy, R., \& Guha, A. K. (2002). An evaluation of street-vended sliced papaya (Carica papaya ) for bacteria and indicator microorganisms of public health significance. Food Microbiology, 19, 663-667.

Roslin, M. R., \& Melewar, T. C. (2008). Hypermarkets and the Small Retailers in Malaysia: Exploring Retailers' Competitive Abilities. Journal of AsiaPacific Business, 329-343.

Samapundo, S., Climat, R., Xhaferi, R., \& Devlieghere, F. (2015). Food safety knowledge, attitudes and practices of street food vendors and consumers in Port-au-Prince, Haiti. Food Control, 50, 457-466.

Schatzki, T. R. (2002). The site of the social: A philosophical account of the constitution of social life and change. Library (p. xxii, 295 p.). University Park: Pennsylvania State University Press.

Shamsuddin, S., \& Ujang, N. (2008). Making places: The role of attachment in creating the sense of place for traditional streets in Malaysia. Habitat International, 32(3), 399-409.

Steel, G. (2012). Local encounters with globetrotters: Tourism's potential for street vendors in Cusco, Peru. Annals of Tourism Research, 39(2), 601-619.

Swislocki, M. (2009). Culinary Nostalgia: Regional food culture and the urban experience in Shanghai (Chapter 5). Stanford: Stanford University Press.

Wijaya, S., King, B., Nguyen, T.-H., \& Morrison, A. (2013). International visitor dining 
experiences: A conceptual framework. Journal of Hospitality and Tourism Management, 20, 34-42.

Wise, A., \& Velayutham, S. (2009). Everyday Multiculturalism. (A. Wise \& S.
Velayutham, Eds.). Basingstoke: Palgrave Macmillan.

Yiftachel, O. (2009). Theoretical notes on "Gray Cities": The coming of urban Apartheid? Planning Theory, 8(1), 88-100. 